\title{
Atypical Palmar Involvement with Erythema Elevatum Diutinum as a Sole Manifestation: A Report of Two Cases
}

This article was published in the following Dove Press journal: Clinical, Cosmetic and Investigational Dermatology

\author{
Ghadah I ALHetheli $\mathbb{D}^{\prime}$ \\ Ohoud Z Aljarbou (1D) ${ }^{2}$ \\ Ahmed ALHumidi ${ }^{3}$ \\ Mohammed I AlJasser $\mathbb{D}^{4}$ \\ 'Division of Dermatology, College of \\ Medicine, Qassim University, Buraidah, \\ Saudi Arabia; ${ }^{2}$ Department of Pathology \\ and Laboratory Medicine, King Abdulaziz \\ Medical City, Riyadh, Saudi Arabia; \\ ${ }^{3}$ Department of Pathology, College of \\ Medicine, King Saud University, Riyadh, \\ Saudi Arabia; ${ }^{4}$ Division of Dermatology, \\ King Saud Bin Abdulaziz University for \\ Health Sciences, Riyadh, Saudi Arabia
}

Correspondence: Ghadah I ALHetheli Division of Dermatology, College of Medicine, Qassim University, Buraidah 56218-6665, Saudi Arabia

Email dr.gadah@gmail.com

\begin{abstract}
Erythema elevated diutinum (EED) is a rare distinctive form of cutaneous leukocytoclastic vasculitis. EED typically presents with asymptomatic symmetrical erythematous-brown papules, nodules or plaques which favor the extensor aspect of extremities while distinctly sparing the palms. We report two cases of EED with a rare presentation limited to the palms.
\end{abstract}

Keywords: palmar vasculitis, erythema elevatum diutinum, streptococcus

\section{Introduction}

Erythema elevatum diutinum (EED) is a rare distinctive form of cutaneous leukocytoclastic vasculitis. It is typically characterized by asymptomatic, symmetrical, firm, erythematous-brownish papules and nodules or plaques which favor the extensor surface of extremities. ${ }^{1,2}$ EED was first described in 1988 in a male patient by Hutchinson ${ }^{3}$ and in a female patient in $1889 .{ }^{4}$ Later on, in 1894 Radcliff-Crocker and William gathered the two types in one entity under the name of EED. ${ }^{3}$ EED can occur at any time during life, but more often affects people in their fourth to sixth decades with no racial variations. However, it can appear earlier in life in patients with Human immunodeficiency virus (HIV). ${ }^{5}$ Herein, we report two distinctive cases of EED with a rare presentation of limited palmar involvement.

\section{Case One}

A 65-year-old male known to have diabetes mellitus presented with a painful palmar rash for 2 weeks. This was preceded 1 week ago with fever and sore throat which resolved after treatment with an oral antibiotic for approximately 1 week. The patient had no history of other respiratory symptoms, abdominal pain, or joint pain. Skin examination revealed multiple purpuric macules and patches affecting both palms (Figure 1). Involvement of the right palm was more prominent. The right big toe had similar findings. Mucous membranes were intact and peripheral lymph nodes were not enlarged. The rest of systemic examination was normal. A skin biopsy from the margin of the proximal part of the right palm was obtained with the differential diagnosis of either vasculitis or vasculopathy related to a thromboembolic process. Biopsy showed perivascular neutrophilic infiltrate with some lymphocytes and few extravasated red blood cells (Figure 2). There was evidence of leukocytoclasia and scattered interstitial neutrophils. A diagnosis 

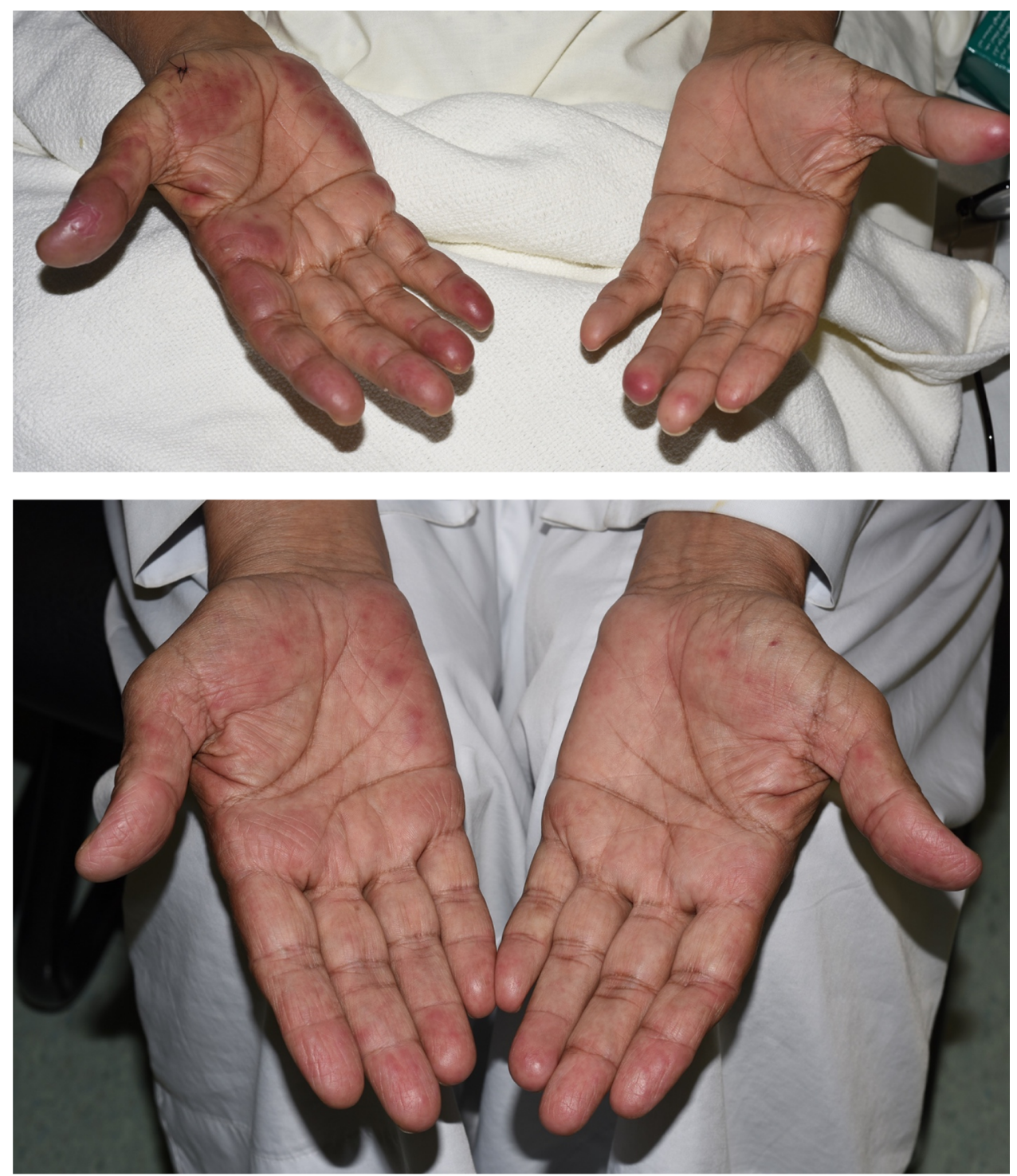

Figure I Multiple painful purpuric macules and patches involving the right palm more than the left palm (Top). Almost complete spontaneous resolution after five months (Bottom).

of early EED as a form of small blood vessel vasculitis was made and vasculitis workup was performed.

Erythrocyte sedimentation rate $(80 \mathrm{~mm} / \mathrm{hr}$; normal range $0-15 \mathrm{~mm} / \mathrm{hr}), \mathrm{C}$-reactive protein $(120 \mathrm{mg} / \mathrm{L}$; normal $<8 \mathrm{mg} / \mathrm{L})$, and serum ferritin $(963 \mu / \mathrm{L}$; normal range $22-275 \mu / L)$ were very high. Antistreptolysin O titer was elevated $(429 \mathrm{IU} / \mathrm{mL}$; normal $<116 \mathrm{IU} / \mathrm{mL})$. Anti-cyclic citrullinated peptide antibody was normal $(3.96 \mathrm{u} / \mathrm{mL}$; normal $<20 \mathrm{u} / \mathrm{mL}$ ). Complete blood count, serum electrolytes, urinalysis, coagulation profile, liver function, and renal profile were all within normal limits. Screening for antinuclear antibody, anti-double-stranded DNA, antineutrophil cytoplasmic antibodies (C-ANCA and P-ANCA), complements, cryoglobulins, serum immunoglobulins, creatine kinase, and antiphospholipid antibodies were normal. Blood, urine, and respiratory cultures were negative. Polymerase chain reaction (PCR) on nasopharyngeal swabs was negative for adenovirus, rhinovirus, coronavirus, influenza viruses, respiratory syncytial virus, and Mycoplasma pneumoniae. Blood cytomegalovirus PCR was negative. Serology for hepatitis B virus, hepatitis C virus, human immunodeficiency virus, and EpsteinBarr virus was negative. Serum protein electrophoresis was normal. Echocardiography and computerized tomography scan of the chest, abdomen, and pelvis did not reveal any abnormality.

Based on the aforementioned findings, the patient was diagnosed with atypical EED secondary to streptococcal 


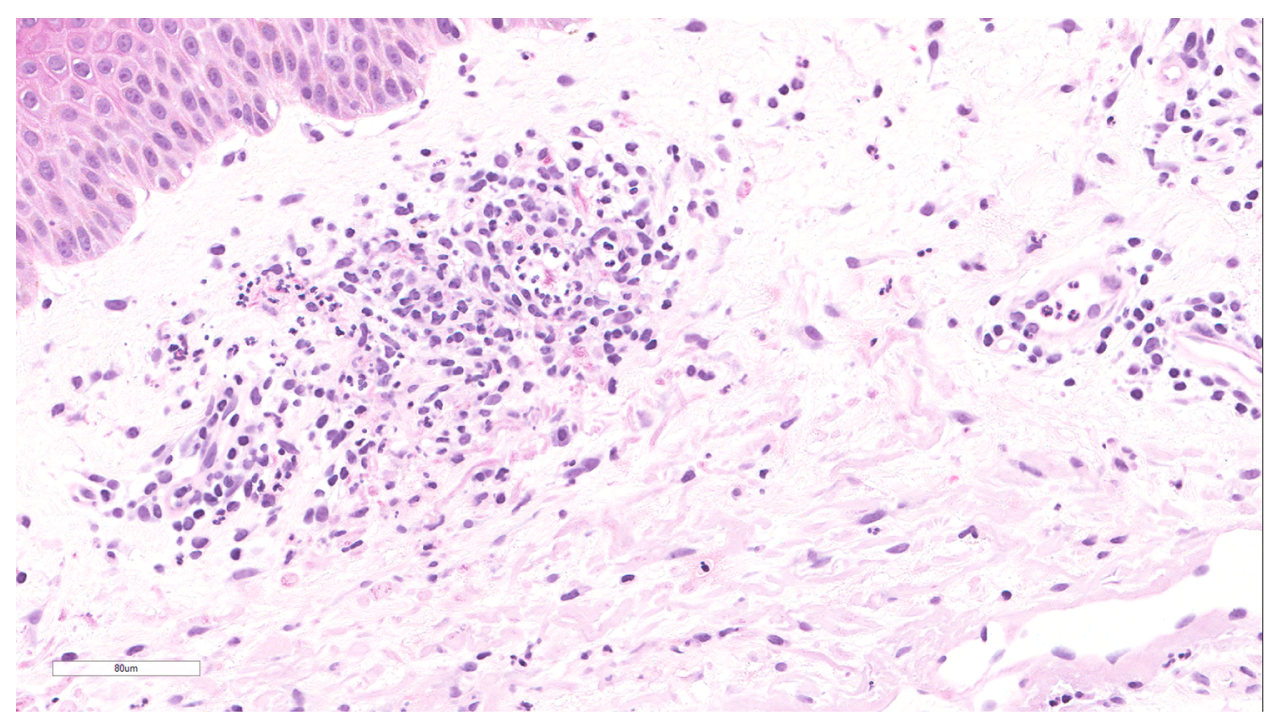

Figure 2 Perivascular neutrophilic infiltrate admixed with lymphocytes and few extravasated red blood cells. Note the nuclear fragmentation and scattered interstitial neutrophils. Magnification X200.

throat infection. Written informed consent has been provided by the patients to have the case details and any accompanying images published. Institutional approval was not required to publish the case details. No therapy was initiated for the throat infection since it was already treated with empirical antibiotics and there were no upper respiratory symptoms or fever. Due to the limited skin involvement, topical tacrolimus $0.1 \%$ and betamethasone dipropionate ointments were applied for 2 weeks with no improvement. The patient continued to have pain in both palms; therefore, prednisolone $30 \mathrm{mg}$ orally once daily was started. This resulted in a significant improvement after a few days. However, the eruption flared up upon tapering prednisolone over 2 months. The patient refused to switch the treatment to colchicine or dapsone. Clobetasol propionate cream was prescribed instead. Five months after the onset of the eruption, there was almost complete resolution of the rash without the use of clobetasol propionate (Figure 1).

\section{Case Two}

A 66-year-old male farmer known to have diabetes mellitus on metformin presented to dermatology clinic with 2-week history of painful palmar lesions restrict his daily work activity. Examination showed erythematous to violaceous plaques limited to both palms (Figure 3). There were no other mucocutaneous, nail, or hair findings. Other clinical systemic enquiry was not remarkable. This rash was preceded by upper respiratory tract infection during which he was treated by a seven-day course of oral antibiotics and analgesics. Our working diagnosis was neutrophilic dermatosis of hands with the differential diagnosis of erythromelalgia and vasculitis.

A $4 \mathrm{~mm}$ punch biopsy was taken from the thenar eminence of Left palm and showed normal epidermis with underlying mixed inflammatory cell infiltrates including fibroblast, histiocytes, lymphocytes, neutrophils and eosinophils. Eosinophils were also seen infiltrating some of the small blood vessels with endothelial cell swelling and few extravasated RBCs. There was an early sign of fibrosis in papillary dermis (Figures 4 and 5). The overall histologic findings were suggestive of early erythema elevatum diutinum (EED). Consequently, diagnosis of leukocytoclastic vasculitis with the suggestion of early EED was made and vasculitis workup was performed.

Complete blood count was normal. Electrolytes, renal function test, liver function test and urine analysis were all normal. Erythrocytes sedimentation rate and rheumatoid factor were normal. Anti-streptolysin $\mathrm{O}$ titer was raised (374 IU/mL; normal <116 IU/mL) Serum protein electrophoresis and serum immunoglobulins were of normal pattern. Anti-nuclear antibodies, anti-double-stranded DNA, and anti-neutrophil cytoplasmic antibodies (C-ANCA and P-ANCA) were all normal. Hepatitis, HIV, Syphilis serology were negative. Chest $\mathrm{x}$-ray and Computed tomography for chest, abdomen and pelvis were both with normal findings.

Depend on the constellation of findings from patient's history and results of whole laboratory and histopathologic workup, the patient was diagnosed with atypical EED 

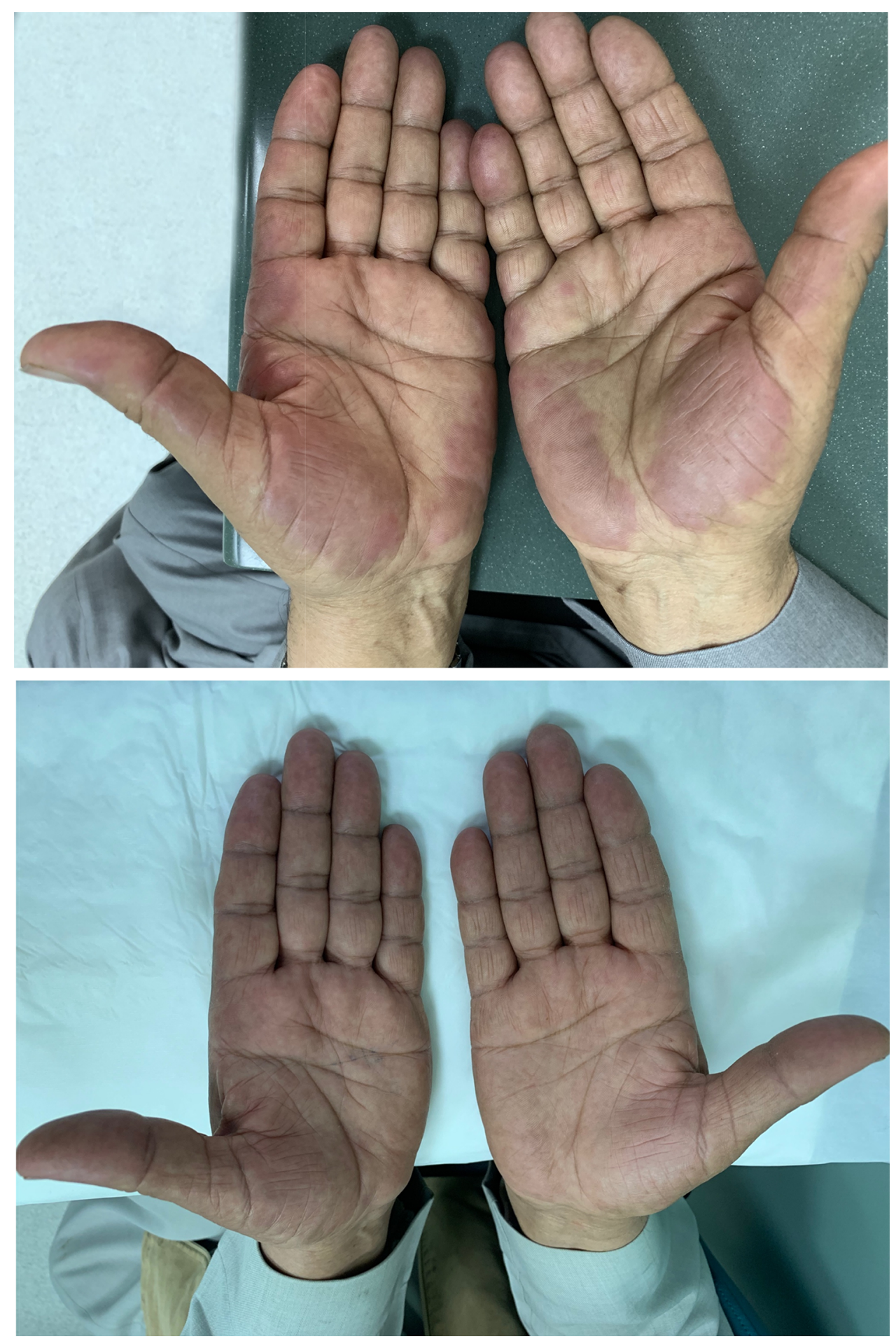

Figure 3 Multiple palmar erythematous to violaceous plaques (Top). Almost complete clearance after 3 months (Bottom).

secondary to streptococcal throat infection. Written informed consent has been provided by the patients to have the case details and any accompanying images published. Institutional approval from Qassim University was not required to publish the case details. Since the patient had already received 7-day course of oral antibiotics and at the time of presentation, there were no symptoms of upper respiratory tract infection or fever, no further antibiotic treatment was initiated. Clobetasol propionate $0.05 \%$ ointment was applied twice daily for 2 weeks, after which there was a marked improvement. The patient had significantly less pain and he was able to do his daily manual work as 

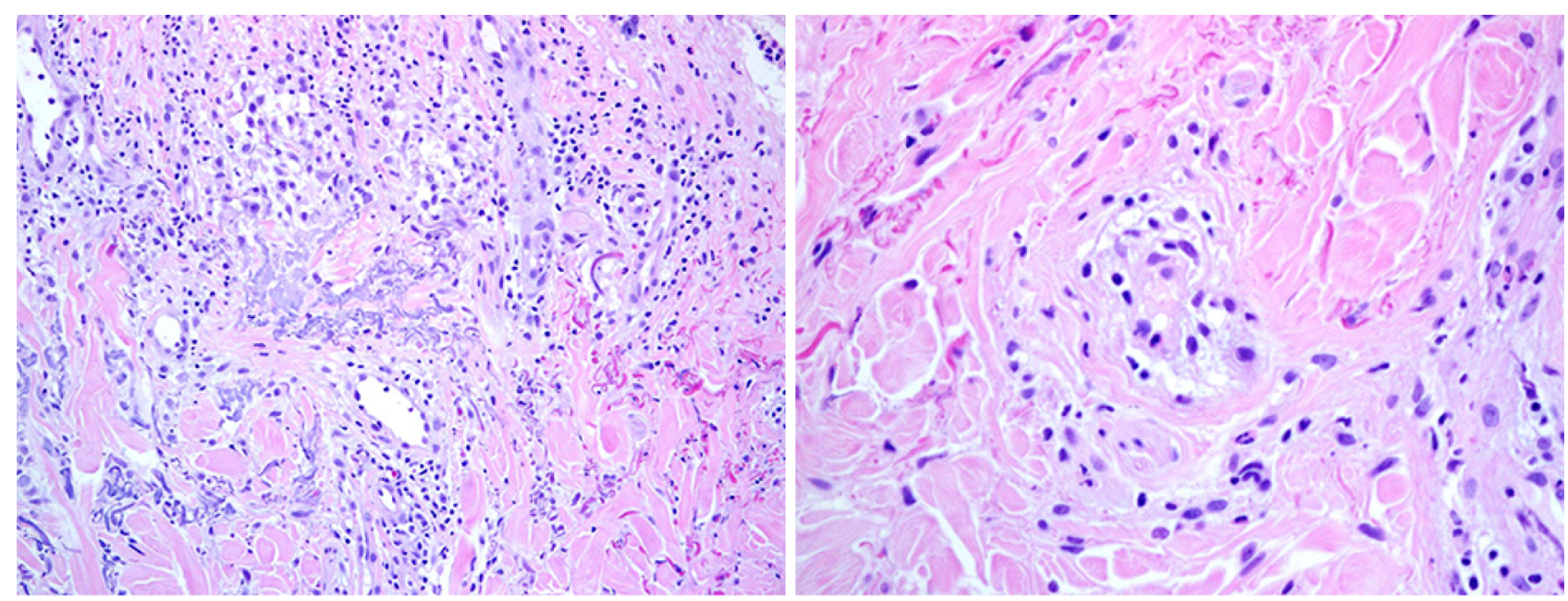

Figure 4 Dermal mixed inflammatory cells infiltrates including histiocytes, lymphocytes, neutrophils and eosinophils. The latter are also seen infiltrating some of small blood vessels. Note endothelial cell swelling and few extravasated RBCs. Magnification X200 (RT) and X400 (LT).

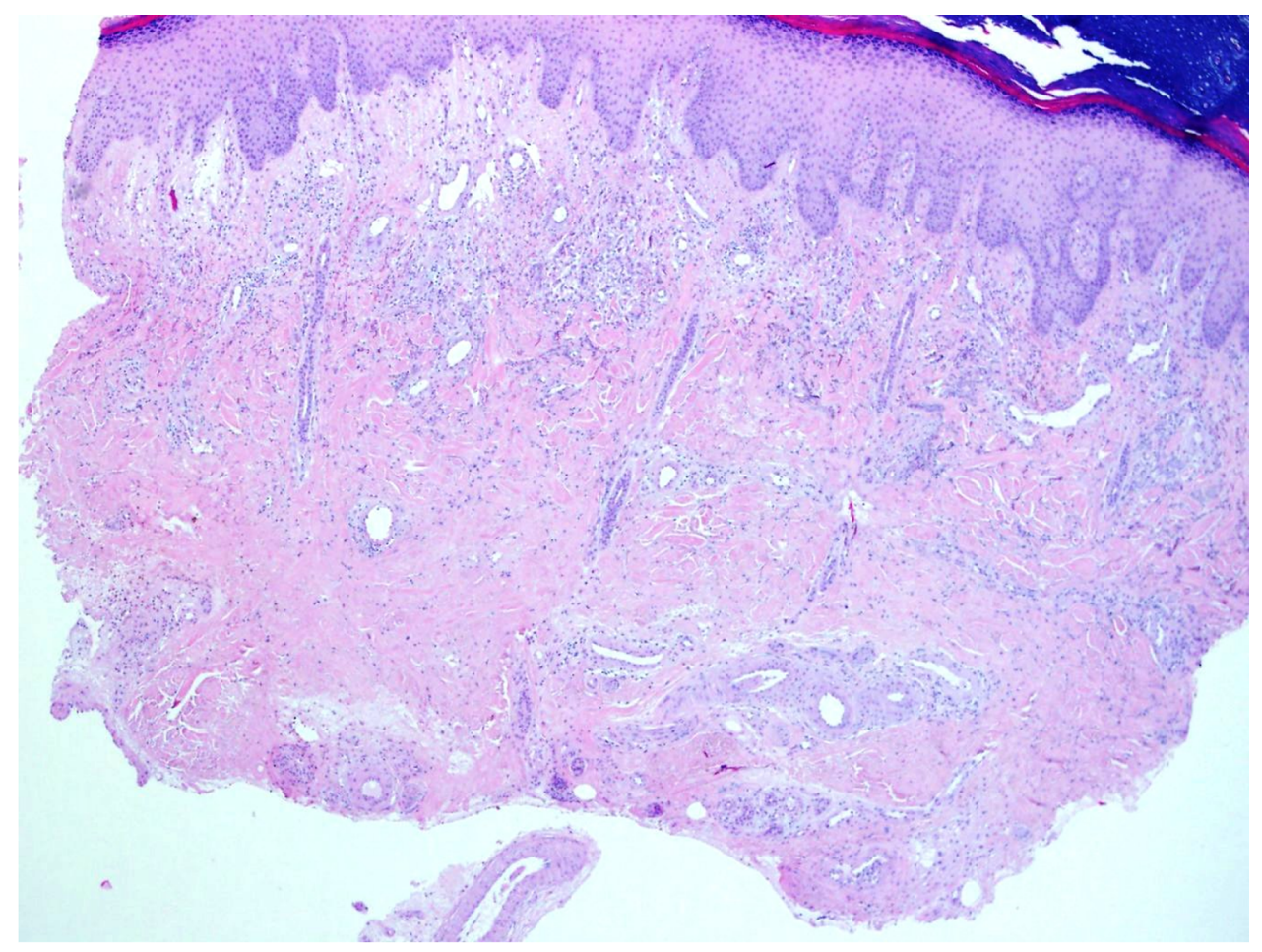

Figure $\mathbf{5}$ The dermis shows Early fibrosis and fibroblasts.

a farmer. Three months after continued topical treatment, the palmar lesions completely cleared (Figure 3 ).

\section{Discussion}

The etiology of EED is not well understood, but it is believed to be related to vascular deposition of circulating immunocomplexes. ${ }^{6}$ EED has been associated with multiple underlying diseases like infections (streptococcal infection, hepatitis $\mathrm{B}$ and $\mathrm{C}$ virus, HIV), ${ }^{7}$ rheumatologic diseases (rheumatoid arthritis, lupus erythematosus), ${ }^{8}$ inflammatory bowel diseases (ulcerative colitis, Crohn's disease) ${ }^{9}$ and hematological disorders like myelodysplasia, ${ }^{10}$ multiple myeloma, ${ }^{11}$ lymphomas (B-cell lymphoma, ${ }^{12}$ non-Hodgkin's lymphoma ${ }^{13}$ ) and paraproteinemias. ${ }^{14}$

EED typically presents with red-violaceous to brown nodules and/or plaques over extensor surfaces. Atypical 
presentation of EED has been reported including truncal involvement. $^{15,16}$ Atypical distribution of EED has also been reported as the first clinical sign of non-Hodgkin's lymphoma. ${ }^{13}$ There have been several cases reported of classic EED presentation along with the involvement of other atypical sites like the palms and soles ${ }^{17-19}$ and the oral mucosa. ${ }^{20}$ Isolated involvement of palms and soles in EED as seen in our cases is very rare. ${ }^{12,21,22}$ This makes the diagnosis more challenging with a high potential to be missed. This is especially true when the other usually affected body sites in EED are spared as seen in our cases.

We report two cases of atypical EED limited to the palms. The typical, acral, symmetrical morphological features together with the age of both patients and the mixed perivascular inflammatory cells infiltrate with the early dermal fibrosis are all in favor of EED. The high ESR in the first case also goes with EED. The histological findings were against the differentials which are neutrophilic dermatosis of hands (variant of sweet syndrome), vasculopathy due to thromboembolic event and erythromelalgia. Even with the literature review, the possible reason behind this was not mentioned by the authors. We believe it is just a different and unusual site of distribution like any other rare presentations of other diseases. Hence, just to do not overlook the possibility of it. Both patients had a preceding streptococcal throat infection. Favorable prognosis with a resolution of lesions within approximately 3-6 months was noted in both cases. Early EED secondary to streptococcal throat infection should be considered in the differential diagnosis of isolated painful palmar erythema.

\section{Disclosure}

The authors report no funding and no conflicts of interest for this work.

\section{References}

1. Gibson LE, el-Azhary RA. Erythema elevatum diutinum. Clin Dermatol. 2000;18:295-299. doi:10.1016/S0738-081X(99)00120-0

2. Yiannias JA, El-Azhary RA, Gibson LE. Erythema elevatum diutinum: a clinical and histopathologic study of 13 patients. JAMA Dermatol. 1992;26:38-44.

3. Hutchinson J. On two remarkable cases of symmetrical purple congestion of the skin in patches, with induration. $\mathrm{Br} J$ Dermatol. 1880;1:10.

4. Bury JS. A case of erythema with remarkable nodular thickening and induration of the skin associated with intermittent albuminuria. Illus Med News. 1889;3:145.
5. Wilkinson SM, English JS, Smith NP, Wilson-Jones E, Winkleman RK. Erythema elevatum diutinum: a clinicopathological study. Clin Exp Dermatol. 1992;17:87-93. doi:10.1111/j.13652230.1992.tb00171.x

6. Cirvidiu DC, Elias BL, Jorge JC, Lira ML, Man- Delbaum SH. Erythema elevatum diutinum and hypothyroidism: coincidence or causal re- lationship? An Bras Dermatol. 2015;90:561-563. doi:10.1590/abd1806-4841.20153284

7. Kim H. Erythema elevatum diutinum in an HIV-positive patient. J Drugs Dermatol. 2003;2:411-412.

8. Woody CM, Lane JE, Davis LS. Erythema elevatum diutinum in the setting of connective tissue disease and chronic bacterial infection. $J$ Clin Rheumatol. 2005;11:98-104.

9. Walker KD, Badame AJ. Erythema elevatum diutinum in a pa- tient with Crohn's disease. J Am Acad Dermatol. 1990;22:948-952.

10. Aractingi S, Bachmeyer C, Dombret H, et al. Simultaneous occurrence of two rare cutaneous markers of poor prognosis in myelodysplastic syndrome: erythemaelevatum diutinum and specific lesions. Br J Dermatol. 1994;131:112-117. doi:10.1111/j.1365-2133.1994. tb08467.x

11. Archimandritis AJ, Fertakis A, Alegakis G, et al. Erythema dietinum and IgA myeloma: an interesting association. BMJ. 1977;2:613-614. doi:10.1136/bmj.2.6087.613-a

12. Futei Y, Konahana I. A case of erythema elevatum diutinum associated with B cell lymphoma: a rare distribution involving palms, soles and nails. Br J Dermatol. 2000;142:116-119. doi:10.1046/ j.1365-2133.2000.03251.x

13. Hatzitolios A, Tzellos TG, Savopoulos C, et al. Erythema elevatum diutinum with rare distribution as a first clinical sign of nonHodgkin's lymphoma: a novel association? J Dermatol. 2008;35 (5):297-300. doi:10.1111/j.1346-8138.2008.00470.x

14. Yiannias JA, el-Azhary RA, Gibson LE. Erythema elevatum diutinum. A clinical and histopathologic study of 13 patients. $J$ Am Acad Dermatol. 1992;26:38-44.

15. Ly H, Black MM. Atypical presentation of erythema elevatum diutinum. Australas J Dermatol. 2005;46(1):44-46. doi:10.1111/ j.1440-0960.2005.00137.x

16. Ben-Zvi GT, Bardsley V, Burrows NP. An atypical distribution of erythema elevatum diutinum. Clin Exp Dermatol. 2014;39 (2):269-270. doi:10.1111/ced.12266

17. García-Meléndez ME, Martínez-Cabriales SA, Eichelmann K, Gómez-Flores M, Ocampo-Candiani J. Erythema elevatum diutinum: an atypical presentation. Am J Med Sci. 2015;349(4):374-375. doi:10.1097/MAJ.0000000000000397

18. Nguyen GH, Guo EL, Norris D. REPORT a rare case of erythema elevatum diutinum presenting as diffuse neuropathy. JAAD Case Rep. 2017;3(1):1-3. doi:10.1016/j.jdcr.2016.10.007

19. Gonçalves MJ, Romão VC, Soares-de-Almeida L, et al. Erythema elevatum diutinum in Crohn's disease-associated spondyloarthritis a rare vasculitis, an unusual association. Acta Reumatol Port. 2017:4:324-328.

20. Maruthappu T, Tharakaram S, Calonje E, Shirlaw PJ, Setterfield J. Erythema elevatum diutinum with oral ulceration. $\mathrm{Br} J$ Dermatol. 2012;167(1):222-224. doi:10.1111/j.1365-2133.2012.10851.x

21. Davatchi CC, Farsinejad K, Nikoo A, Akhyani M, Daneshpazhooh M, Barzegar M. An atypical presentation of erythema elevatum diutinum involving palms and soles. Int J Dermatol. 2008;48(1):73-75.

22. Keyal U, Bhatta AK, Liu Y. Erythema elevatum diutinum involving palms and soles: a case report and literature review. Am J Transl Res. 2017;9(4):1956-1959. 


\section{Publish your work in this journal}

Clinical, Cosmetic and Investigational Dermatology is an international, peer-reviewed, open access, online journal that focuses on the latest clinical and experimental research in all aspects of skin disease and cosmetic interventions. This journal is indexed on CAS
The manuscript management system is completely online and includes a very quick and fair peer-review system, which is all easy to use. Visit http://www.dovepress.com/testimonials.php to read real quotes from published authors. 